\title{
S1PR2 Gene
}

National Cancer Institute

\section{Source}

National Cancer Institute. S1PR2 Gene. NCI Thesaurus. Code C104773.

This gene is involved in both cell proliferation and cell survival. 